\title{
Recruitment dynamics of coral reef fishes in Barbados
}

\author{
M. Tupper ${ }^{1, *}$, W. Hunte ${ }^{1,2}$ \\ ${ }^{1}$ Bellairs Research Institute of McGill University, St. James, Barbados \\ ${ }^{2}$ Biology Department, University of the West Indies, Cave Hill, Barbados
}

\begin{abstract}
Recruitment and population density of coral reef fishes were studied on artificial and natural reefs on the west coast of Barbados. Recruitment of all species combined and of 3 common species (Thalassoma bifasciatum, Stegastes partitus and Halichoeres garnoti) occurred mostly from May to November. Recruitment rate varied little across reef types and reef locations. Population density of all species combined and of the 3 common species varied little throughout the year, but did vary across reets and locations. The observation that patterns of seasonal and spatial variation in densities did not reflect the patterns of seasonal and spatial variation in recruitment suggests that reef fish populations in Barbados may be primarily regulated by post-settlement events. Recruitment of all species combined and of the 3 common species was not affected by the density of all species combined. No evidence could be found for interspecific competition, i.e. a negatıve relatıonship between the density of one species and the recruitment of another. However, recruitment of H. garnoti was inhibited on some reefs by high densities of conspecifics. Post-recruitment mortality of all species combined was not affected by density of all species. However, post-recruitment mortality of $T$. bifasciatum and $S$. partitus was higher on reefs of higher conspecific density. These results provide evidence for the regulation of reef fish populations in Barbados by post-settlement processes, and suggest that intraspecific interactions may be particularly important in limiting population size.
\end{abstract}

KEY WORDS: Recruitment - Reef fishes - Density dependence

\section{INTRODUCTION}

Coral reef fish assemblages are characterized by high species diversity and high population densities (Sale 1980). All but one of the several thousand fish species known to inhabit coral reefs exhibit a bipartite life cycle with a pelagic larval stage (Robertson 1973). During the larval stage there is potential for widespread dispersal but mortality is extreme. The mechanisms whereby larvae return to the vicinity of reefs are unknown (Sale 1980, Williams et al. 1986) but are assumed to be largely passive. After recruitment to the reef, movement of fishes between reefs is assumed to

- Present address and address for correspondence: PO Box 412, Woods Hole, Massachusetts 02543, USA be negligible (e.g. Sale \& Ferrell 1988, Connell \&Jones 1991).

There are 2 major hypotheses on the population dynamics of coral reef fishes, each emphasizing a different life history stage. These are the equilibrium for 'space-limitation') hypothesis and the non-equilibrium (or 'recruitment-limitation') hypothesis (Doherty \& Williams 1988). The former states that population densities of reef fishes and the structure of reef fish assemblages are regulated by post-recruitment competition for resources on the reef (Shulman et al. 1983, Shulman 1984, 1985a, b, Jones 1986, 1987a, 1990). This competition may take 2 forms. The 'single-species equilibrium' model suggests that interspecific competition has led to the evolution of species-specific resource requirements which allow stable coexistence of many species on one reef (Ogden \& Ebersole 1981, Bohnsack 1983). The consequence is a reef fish assem- 
blage in which individual species populations are controlled by intraspecific density-dependent mechanisms, and therefore remain relatively constant through time (Hunt von Herbing \& Hunte 1991). The 'multi-species equilibrium' model suggests that several species have similar resource requirements and that competition is therefore both intraspecific and interspecific (Sale 1977, 1978). The consequence is that whole species groups are controlled by density-dependent competitive mechanisms, and therefore that the total standing stock of fishes on the reef remains relatively constant even though the population size of individual species may vary due to recruitment variability. It is not clear how the processes envisaged by this model facilitate species coexistence.

The non-equilibrium or 'recruitment-limitation' hypothesis suggests that stochastic pre-recruitment (planktonic) processes limit the numbers of larvae available for settlement to reefs (Doherty 1982, 1983, Victor 1983, 1986, Milicich et al. 1992). Population densities of reef fishes are therefore below numbers set by available reef resources, and variation in species population densities on reefs reflects variation in the abundance of conspecific recruits. The consequence is that both population numbers of individual species and the total standing crop of reef fish will vary both spatially and temporally (Sale 1991).

While the above models have been dealt with separately for the sake of convenience, they should not be considered mutually exclusive. Both recruitment and post-recruitment events influence the demography of reef fishes (Forrester 1990). The relative importance of each of these processes may vary between populations, or within a population from year to year or location to location (Jones 1991). Below a certain level of recruitment, populations will be limited by larval supply; above that level, post-recruitment processes such as predation and competition become increasingly important (Jones 1990).

One approach to addressing the issue of whether reef fish populations are 'space-limited' sensu the single-species equilibrium model, 'space-limited' sensu the multi-species equilibrium model, or 'recruitment-limited' is the investigation of 'prior resident effects' (Shulman et al. 1983). Two types of prior resident effects may occur. First, residents may interfere with settlement through aggression or by pre-empting resources; second, residents may increase post-recruitment mortality to the point of density-dependence either by preying on recruits or out-competing them for resources (Shulman et al. 1983, Forrester 1990, Jones 1990). Under 'single-species space-limitation', prior resident effects should be evident but should occur within species; under 'multi-species spacelimitation', prior resident effects should be evident but should also occur between species; and under 'recruitment-limitation', prior resident effects should be negligible.

The objective of this paper is to assess which of the 3 models described above is most applicable to reef fish populations in Barbados, by investigating (1) temporal and spatial variation in recruitment and population density of reef fishes in Barbados, (2) the effects of recruitment on older juvenile and adult population density (i.e. are patterns of recruitment reflected in the adult population?), and (3) the effects of resident density on rates of recruitment and post-recruitment mortality (i.e. do high densities of resident conspecifics inhibit recruitment and/or increase post-recruitment mortality?).

\section{METHODS}

Census techniques. Recruitment and population density of reef fishes were monitored using SCUBA on a large $\left(100 \mathrm{~m}^{2}\right)$ artificial reef and an equal area of nearby natural reef, at each of 2 sites (Miramar \& Heywoods) on the west coast of Barbados (see Hunte 1987 , Tupper 1989). Many studies of reef fish recruitment have used artificial reefs exclusively (e.g. Ogden \& Ebersole 1981), while others have used only natural coral or rock reefs (e.g. Hunt von Herbing \& Hunte 1991). This design allowed us to compare artificial and natural reefs, in order to investigate the possibility that the type of reef used influences the results of a recruitment study.

Each artificial reef consisted of 10 derelict cars and was deployed within $20 \mathrm{~m}$ of the nearest natural reef in April 1986. The reefs were censused twice monthly from July 1987 to June 1988. At each census, demersal species were counted while the diver swam slowly across the reef about $1 \mathrm{~m}$ above the surface. Benthic and cryptic species and newly settled individuals were counted by carefully searching holes and crevices in the reef substrate. All individuals of all species were recorded on a Perspex slate and grouped according to size/age as follows:

Recruits: Post-larvae or very young juveniles, recently settled and metamorphosed. Information on typical sizes of newly recruited individuals of each species was obtained from the literature where possible.

Juveniles: Individuals larger than those as defined by the above category, but smaller than the size at sexual maturity for the species. Typically, recruits in any one census would be recorded as juveniles by the time of the following census.

Adults: Individuals larger than the size at sexual maturity for the species. 
Statistical analyses. The null hypothesis that recruitment and population density did not vary temporally was tested using the Kolmogorov-Smirnoff OneSample analysis to determine significant differences between the distribution of recruits (or juveniles and adults) among censuses from a hypothetical discrete uniform distribution (Wilkinson 1990). Where no significant differences were found, recruitment or density could not be said to vary significantly over time. The test was carried out separately for each reef in order to determine the effects of reef type (artificial vs natural) and reef location (Heywoods vs Miramar).

Spatial variation in recruitment and population density was analyzed using the Kruskal-Wallis nonparametric analysis of variance, since various transformations failed to normalize the data or stabilize the variance (Bartlett's test for homogeneity of variance, $p<0.05$ for all census data). For this analysis, reefs were considered fixed treatment effects, while censuses were considered random effects and a repeated measure. Where significant results were obtained by Kruskal-Wallis tests, multiple comparisons of means were performed using the simultaneous test procedure (STP; Sokal \& Rohlf 1981).

Effects of resident density on recruitment were andlyzed by Spearman rank correlations of the number of resident fishes in a given census versus the number of new recruits in that census. A significant positive correlation would indicate that the presence of resident fishes facilitates recruitment; a significant negative correlation

Table 1. Kolmogorov-Smirnoff One-Sample test of uniformity in the temporal distribution of recruitment of reef fishes to the 2 artificial and 2 natural reefs in Barbados. D: KolmogorovSmirnoff test statistic, a measure of departure from uniformity. MA: Miramar artificial: MN: Miramar natural; HA: Heywoods artificial; HN: Heywoods natural. ns: not significant

\begin{tabular}{|lllc|}
\hline Species & Reef & $D$ & $\mathrm{p}$ \\
\hline All species combined & MA & 0.38 & $<0.05$ \\
& MN & 0.41 & $<0.05$ \\
& HA & 0.29 & $<0.05$ \\
& HN & 0.34 & $<0.05$ \\
Thalassoma bifasciatum & MA & 0.31 & $<0.05$ \\
& MN & 0.20 & ns \\
& HA & 0.18 & ns \\
Stegastes partitus & HN & 0.49 & $<0.05$ \\
& MA & 0.40 & $<0.05$ \\
& MN & 0.44 & $<0.05$ \\
& HA & 0.52 & $<0.01$ \\
Halichoeres garnoti & HN & 0.48 & $<0.05$ \\
& MA & 0.30 & $<0.05$ \\
& MN & 0.35 & $<0.05$ \\
& HA & Insufficient data \\
& HN & 0.32 & $<0.05$ \\
\hline
\end{tabular}

would indicate that the presence of resident fishes inhibits recruitment. Where multiple comparisons were made (i.e. between groups of species), probability values were adjusted using the Dunn-Sidak method for experimentwise error rates (Sokal \& Rohlf 1981).

Effects of resident density on post-recruitment mortality were investigated by Spearman rank correlations of density of residents versus an index of post-recruitment mortality. The index of post-recruitment mortality used $\left(I_{m}\right)$ was the decline in recruit density from its maximum value in any recruitment period to its value at the end of the recruitment period (see Hunt von Herbing \& Hunte 1991). $I_{\mathrm{m}}$ is calculated as:

$$
I_{\mathrm{m}}=\left(\mathrm{D}_{\mathrm{pr}}-\mathrm{D}_{\mathrm{erp}}\right) / \mathrm{D}_{\mathrm{pr}}
$$

where $D_{p r}$ represents the density at the time of peak recruitment and $D_{\operatorname{erp}}$ represents the density at the end of the recruitment period. Note that this index underestimates mortality since it does not discount for recruits added to the reef during the latter part of the recruitment period.

\section{RESULTS}

\section{Temporal variation in recruitment rates}

Sixty-seven species belonging to 26 families were observed on the car reefs and their nearest natural reefs. However, 3 common resident species accounted for over $90 \%$ of all recruitment on the 4 reefs. These were the bluehead wrasse Thalassoma bifasciatum, the bicolor damselfish Stegastes partitus, and the yellowhead wrasse Halichoeres garnoti. Recruitment of all species pooled was not uniform throughout the year (Table 1). On all 4 reefs, recruitment was low between December and April, and high between May and November (Fig. 1a).

Temporal variation in recruitment of the 3 common species can be considered separately. Recruitment of Thalassoma bifasciatum was not uniform throughout the year on 2 of the 4 study reefs (Table 1 ). Recruitment on these 2 reefs peaked in June to September and remained low from December until April (Fig. 1b). Recruitment to the Heywoods artificial reef and Miramar natural reef did not differ from uniform. Recruitment of Stegastes partitus was also not uniform throughout the year on any of the reefs (Table 1 ). Recruitment of this species peaked during June to September and was low from November to April (Fig. 1c). Recruitment of Halichoeres garnoti on the Heywoods artificial reef was too low to justify analysis. On the other 3 reefs, recruitment was not uniform throughout the year (Table 1 ). Recruitment was highest from June to October and lowest from November to April (Fig. 1d). The results 

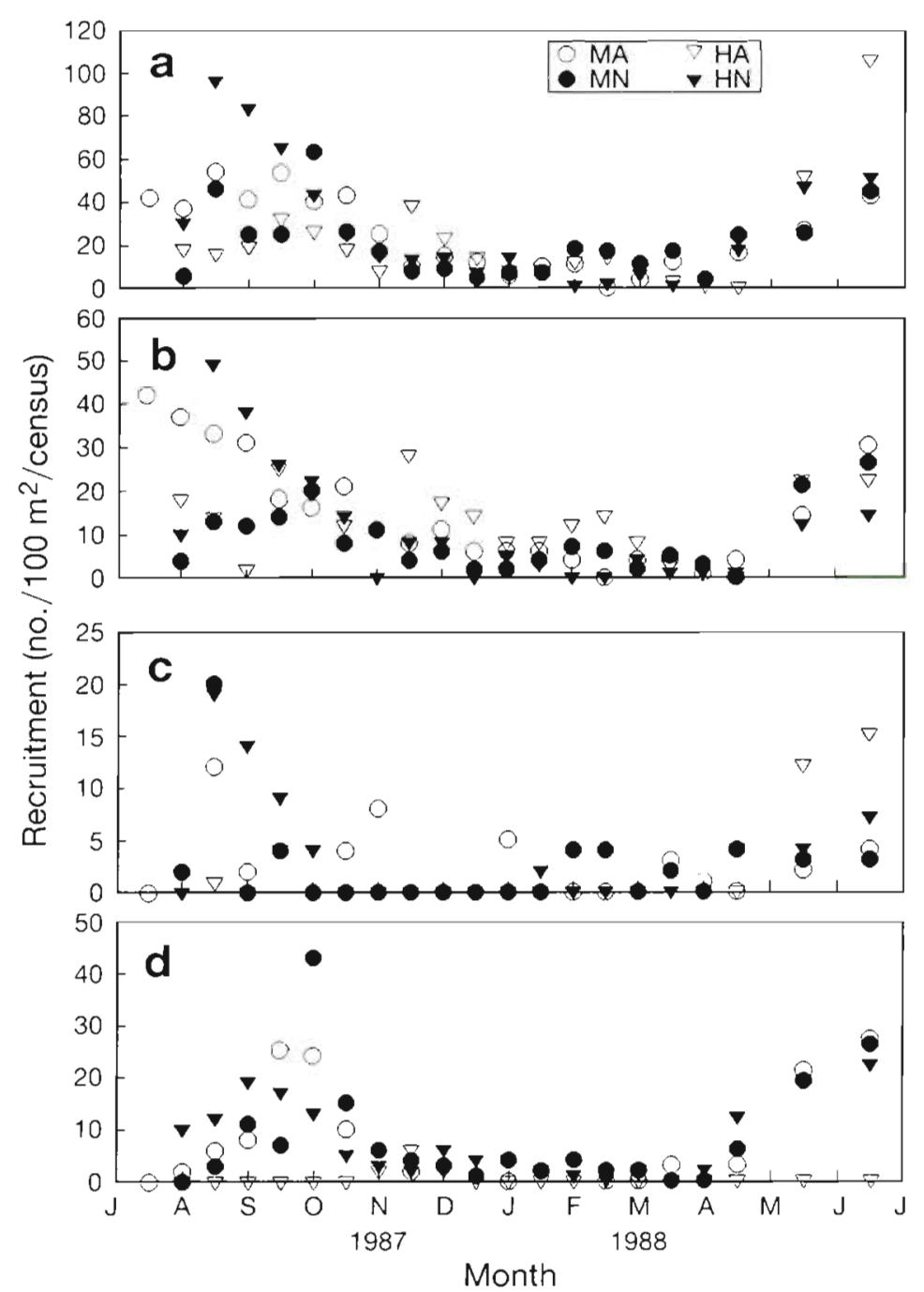

Fig. 1. Temporal variation in recruitment of fish (no. of recruits per $100 \mathrm{~m}^{2}$ per biweekly census) to 2 artificial and 2 natural reefs in Barbados, from July 1987 to June 1988. MA: Miramar artificial, MN: Miramar naturali HA: Heywoods artificial; HN: Heywoods natural. Missing data in May and June are due to spring storms. (a) All species combined, (b) Thalassoma bifasciatum, (c) Stegastes partitus, (d) Halichoeres garnoti

indicate that on most reefs, the temporal pattern of recruitment of combined species and of the 3 common species differed significantly from a uniform distribution, i.e. recruitment varied significantly over time.

\section{Temporal variation in population densities}

In contrast to recruitment rates, the population density of all species combined (Fig. 2a) did not differ significantly from uniform throughout the year on any of the reefs (Table 2). Temporal variation in population densities of the 3 common species can be considered separately. On all 4 reefs, density of Thalassoma bifas- ciatum (Fig. 2b) was not significantly different from uniform throughout the year, although there was a trend towards temporal variation on Heywoods artificial reef (Table 2). As with $T$. bifasciatum, density of Stegastes partitus (Fig. 2c) was not significantly different from uniform throughout the year on any of the 4 reefs (Table 2). Density of Halichoeres garnoti (Fig. 2d) on the Heywoods artificial reef was too low to justify analysis. Density of $H$. garnoti on the Miramar natural reef was not uniform throughout the year, showed some variation on the Miramar artificial reef, but was uniform throughout the year on the Heywoods natural reef (Table 2). On the Miramar reefs, recruitment was high relative to the density of resident juveniles and adults. Consequently, the density of the total population tended to reflect the seasonal variation in recruitment. In summary, for most species on most reefs, population density over the 12 mo study period did not differ significantly from a uniform distribution, i.e. did not vary significantly over time.

\section{Spatial variation in recruitment rates}

Biweekly recruitment is expressed as the mean number of recruits observed in the biweekly censuses conducted over the 12 mo study period. The effect of reef location on biweekly recruitment of all species combined and of the 3 common species was investigated over the recruitment season (May to November). Recruitment of all species combined and Thalassoma bifasciatum did not differ significantly between the 4 study reefs [Kruskal-Wallis Test, $H=23.2$, $\mathrm{p}>0.05$, and $H=27.0, \mathrm{p}>0.05$, respectively (Table 3)]. Recruitment of Stegastes partitus was negligible on the Heywoods artificial reef, but did not differ between the other 3 reefs $(H=18.1, p>0.05)$. Recruitment of Halichoeres garnoti was also negligible on the Heywoods artificial reef, but again did not differ between the other 3 reefs $(H=29.4, \mathrm{p}>0.05)$. The low recruitment of these 2 species to the Heywoods artificial reef may be due to that reef's greater isolation from the nearest natural reef (see Tupper 1989).

In summary, recruitment strength for all species combined and for 2 of the 3 common species did not differ significantly between the 4 study reefs over the recruitment season. This suggests that seasonal patterns in recruitment are coherent on a scale of several 
kilometers (Heywoods vs Miramar sites) or several meters (artificial vs natural reefs at each site), and that the type of reef (artificial vs natural) does not markedly influence recruitment.

\section{Spatial variation in population densities}

The juvenile and adult density on each reef, expressed as the mean number of juveniles and adults in the biweekly censuses for $100 \mathrm{~m}^{2}$ of reef over the post-recruitment period (December to April), is shown for all species combined and for common species separately in Table 4. The population density of all species combined differed significantly across reefs during the post-recruitment period (Kruskal-Wallis Test, $H=59.1, p<$ 0.05). Comparing sites separately for artificial and natural reefs, density of combined species was lower on the Heywoods artificial reef than on the Miramar artificial reef, but was lower on the Miramar natural reef than on the Heywoods natural reef. Comparing artificial and natural reefs, density of combined species was lower on the Miramar natural reef than on the Miramar artificial reef, but did not differ between the Heywoods artificial reef and the Heywoods natural reef.

Population density of Thalassoma bifasciatum was not uniform across reefs, being particularly high on the Heywoods natural reef (Kruskal-Wallis Test, $H=44.7, p<0.05$, Table 4). In paired comparisons between sites, density was higher on Heywoods artificial than Miramar artificial reef, but Miramar natural reef had a lower density than Heywoods natural reef. Comparing artificial with natural reefs, density of $T$. bifasciatum was lower on Heywoods artificial reef than on Heywoods natural reef, but was lower on the Miramar natural reef than on Miramar artificial reef. Population density of Stegastes partitus was also not uniform across reefs ( $H=$ 57.3, $\mathrm{p}<0.05$; Table 4). In pairwise comparisons of sites, population density was lower on the Heywoods artificial reef than on the Miramar artificial reef, but was lower on the Miramar natural reef than on the Heywoods natural reef. Comparing artificial with natural reefs, density of $S$. partitus was lower on the Heywoods artificial reef than on the Heywoods natural reef, but was lower on Miramar natural reef than on Miramar artificial reef. Population density of Halichoeres garnoti was again not uniform across reefs $(H=$ 39.5, p $<0.05$; Table 4), and was particularly low on the
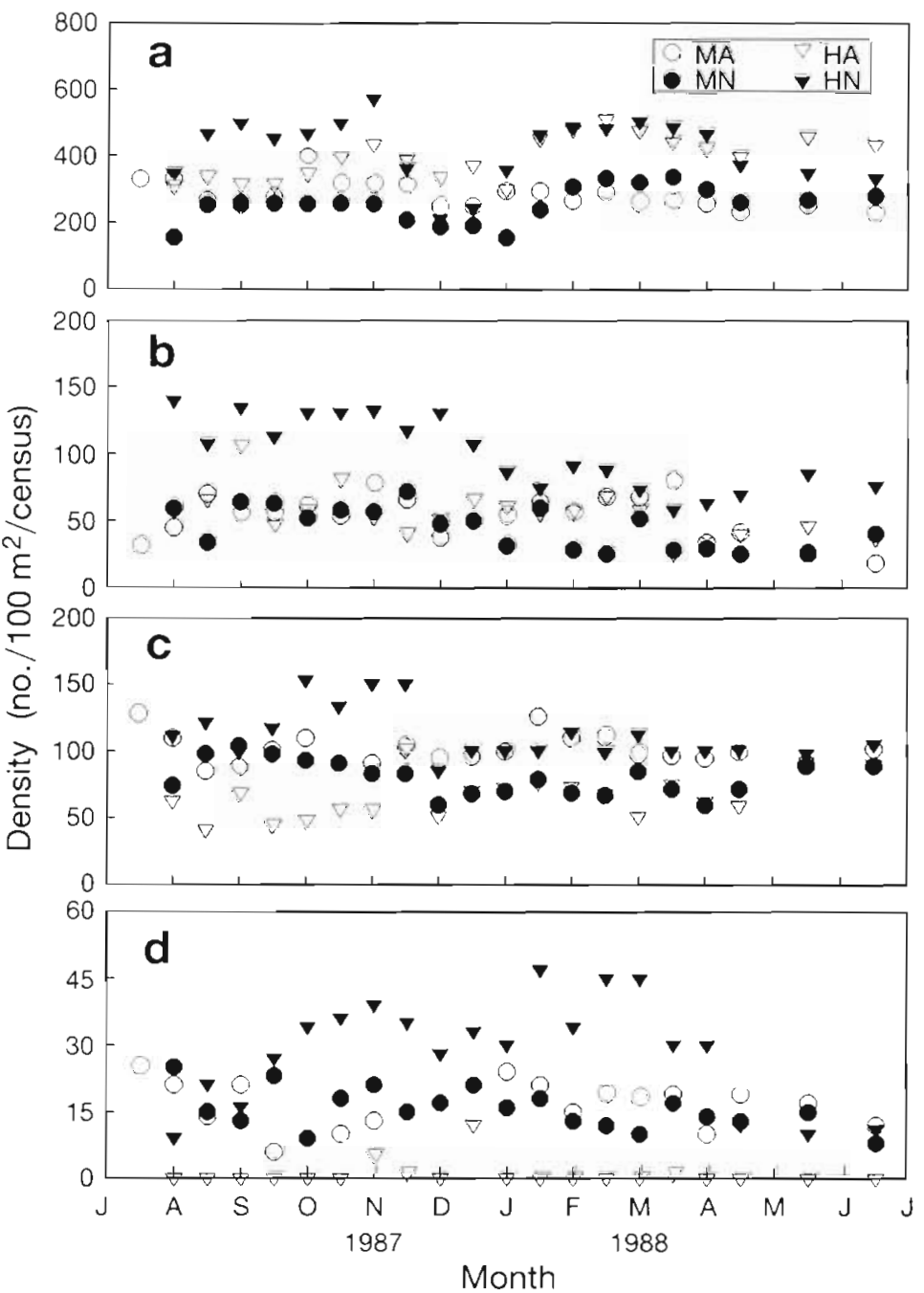

Fig. 2. Temporal variation in density of fish (no. of juveniles and adults per $100 \mathrm{~m}^{2}$ per biweekly censusi on 2 artificial and 2 natural reefs in Barbados, from July 1987 to June 1988. Missing data in May and June are due to spring storms. (a) All species combined, (b) Thalassoma bifasciatum, (c) Stegastes partitus, (d) Halichoeres garnoti

Heywoods artificial reef. In paired comparisons of sites, population density on the Heywoods artificial reef was lower than that on the Miramar artificial reef, but was lower on the Miramar natural reef than on the Heywoods natural reef. Comparing artificial with natural reefs, density of $H$. garnoti was lower on Heywoods artificial reef than on Heywoods natural reef, and did not differ between reef types at Miramar. In summary, population density of combined species and of the 3 common species differed across the 4 study reefs over the 12 mo period. The differences in population densities could not be attributed to reef location or reef type (artificial vs natural), but may be partly explained by the differences in substrate complexity and isolation of the study reefs (see Tupper 1989). Since the study reefs did not differ in recruitment for 
Table 2. Kolmogorov-Smirnoff One-Sample test of uniformity in the temporal distribution of population density of reef fishes on the 2 artificial and 2 natural reefs in Barbados. D: Kolmogorov-Smirnoff test statistic, a measure of departure from uniformity. MA: Miramar artificial; MN: Miramar natural, $\mathrm{HA}$ : Heywoods artificial; HN: Heywoods natural. ns: not significant

\begin{tabular}{|lccc|}
\hline Species & Reef & $D$ & $\mathrm{p}$ \\
\hline All species combined & MA & 0.04 & $\mathrm{~ns}$ \\
& MN & 0.07 & $\mathrm{~ns}$ \\
& $\mathrm{HA}$ & 0.11 & $\mathrm{~ns}$ \\
Thalassoma bifasciatum & $\mathrm{HN}$ & 0.15 & $\mathrm{~ns}$ \\
& $\mathrm{MA}$ & 0.05 & $\mathrm{~ns}$ \\
& $\mathrm{HA}$ & 0.13 & $\mathrm{~ns}$ \\
& $\mathrm{HN}$ & 0.28 & 0.06 \\
Stegastes partitus & $\mathrm{MA}$ & 0.12 & $\mathrm{~ns}$ \\
& $\mathrm{MN}$ & 0.20 & $\mathrm{~ns}$ \\
& $\mathrm{HA}$ & 0.07 & $\mathrm{~ns}$ \\
Halichoeres garnoti & $\mathrm{HN}$ & 0.03 & $\mathrm{~ns}$ \\
& $\mathrm{MA}$ & 0.27 & 0.08 \\
& $\mathrm{MN}$ & 0.41 & $<0.05$ \\
& $\mathrm{HA}$ & Insufficient data \\
& $\mathrm{HN}$ & 0.18 & $\mathrm{~ns}$ \\
& & & \\
& & &
\end{tabular}

any of the species studied but did differ in population densities, the variation in density of a species across reefs cannot be the consequence of variation in its recruitment, but must be due to post-settlement events.

\section{Prior resident effects}

Spearman rank correlation coefficients of number of recruits in each biweekly census versus the juvenile and adult density of all species combined at the time of the census are shown for the 12 mo study period in Table 5 .

Table 3. Kruskal-Wallis Test of among-reef variation in recruitment rates of reef tishes (no. of recruits per $100 \mathrm{~m}^{2}$ per biweekly census) over the recruitment period (May to November) on the Miramar and Heywoods artificial and natural reefs. MA: Miramar artificial reef; MN: Miramar natural reef; HA: Heywoods artificial reef; HN: Heywoods natural reef; ns: not significant. Lines connect recruitment strengths of no significant difference, as determined by STP

\begin{tabular}{|c|c|c|c|c|c|}
\hline Species & \multicolumn{4}{|c|}{ Mean biweekly recruitment } & $\mathrm{p}$ \\
\hline All species combined & $\begin{array}{l}\mathrm{HA} \\
22.2 \\
\end{array}$ & $\begin{array}{l}M N \\
23.0\end{array}$ & $\begin{array}{l}\text { MA } \\
33.0\end{array}$ & $\begin{array}{l}\mathrm{HN} \\
40.1\end{array}$ & ns \\
\hline Thalassoma bifasciatum & $\begin{array}{r}\mathrm{MN} \\
9.4 \\
\end{array}$ & $\begin{array}{l}\text { HA } \\
14.9\end{array}$ & $\begin{array}{l}\mathrm{HN} \\
17.5\end{array}$ & $\begin{array}{l}\text { MA } \\
19.2\end{array}$ & ns \\
\hline Stegastes partitus & $\begin{array}{r}\mathrm{HA} \\
\underline{0.9}\end{array}$ & $\begin{array}{r}\text { MA } \\
\underline{3.2}\end{array}$ & $\begin{array}{r}\mathrm{MN} \\
3.4\end{array}$ & $\begin{array}{r}\mathrm{HN} \\
4.6 \\
\end{array}$ & $<0.05$ \\
\hline Halichoeres garnoti & $\begin{array}{l}\mathrm{HA} \\
\underline{1.0}\end{array}$ & $\begin{array}{r}\mathrm{MA} \\
8.7\end{array}$ & $\begin{array}{r}\mathrm{HN} \\
9.1\end{array}$ & $\begin{array}{r}M N \\
9.3\end{array}$ & $<0.05$ \\
\hline
\end{tabular}

Table 4. Kruskal-Wallis Test of Comparison of among-reef variation in the density (no. per $100 \mathrm{~m}^{2}$ per biweekly census) of reef fishes over the post-recruitment period (December to April) on the Miramar and Heywoods artificial and natural reefs. MA: Miramar artificial reef; MN: Miramar natural reef; HA: Heywoods artificial reef; HN: Heywoods natural reef Lines connect densities of no significant difference, as determined by STP

\begin{tabular}{|lcccccc|}
\hline Species & Mean biweekly recruitment & $\mathrm{p}$ \\
\hline All species combined & $\mathrm{MA}$ & $\mathrm{MN}$ & $\mathrm{HN}$ & $\mathrm{HA}$ & \\
& $\underline{259.9}$ & $\underline{294.1}$ & $\underline{436.1}$ & 451.0 & $<0.05$ \\
Thalassoma bifasciatum & $\mathrm{MN}$ & $\mathrm{HA}$ & $\mathrm{MA}$ & $\mathrm{HN}$ & \\
& $\underline{35.2}$ & $\underline{48.1}$ & $\underline{51.1}$ & $\underline{76.3}$ & $<0.05$ \\
Stegastes partitus & $\mathrm{HA}$ & $\mathrm{MN}$ & $\mathrm{HN}$ & $\mathrm{MA}$ & \\
& $\underline{71.8}$ & 75.2 & $\underline{102.9}$ & 103.0 & $<0.05$ \\
Halichoeres garnoti & $\mathrm{HA}$ & $\mathrm{MA}$ & $\mathrm{MN}$ & $\mathrm{HN}$ & \\
& $\underline{0.1}$ & 14.6 & $\underline{17.3}$ & $\underline{29.4}$ & $<0.05$ \\
& & & & & & \\
& & & & & &
\end{tabular}

The coefficients are presented separately for each reef, and for combined recruits, recruits of Thalassoma bifasciatum, recruits of Stegastes partitus and recruits of Halichoeres garnoti. We chose the 3 most common species for these analyses for 2 reasons. First, agonistic interactions between these species were seen on almost every dive; juveniles and adults of the 2 labrid species were often observed chasing heterospecific recruits

Table 5. Spearman rank correlation coefficients $\left(\mathrm{r}_{\mathrm{S}}\right)$ of number of recruits in each biweekly census during the recruitment period (May to November) versus juvenile and adult density of all species combined at the time of the census. Data are presented separately for each reef, and separately for combined recruits of all species and for recruits of Thalassoma bifasciatum, Stegastes partitus, and Halichoeres garnoti. Probabilities have been adjusted using the Dunn-Sidak method for experimentwise error rate. MA: Miramar artificial; MN: Miramar natural; HA: Heywoods artificial; HN: Heywoods natural. ns: not significant

\begin{tabular}{|lcrc|}
\hline Species & Reef & rs & $\mathrm{p}$ \\
\hline All species combined & $\mathrm{MA}$ & -0.05 & $\mathrm{~ns}$ \\
& $\mathrm{MN}$ & -0.39 & $\mathrm{~ns}$ \\
& $\mathrm{HA}$ & -0.36 & $\mathrm{~ns}$ \\
& $\mathrm{HN}$ & 0.15 & $\mathrm{~ns}$ \\
Thalassoma bifasciatum & $\mathrm{MA}$ & 0.10 & $\mathrm{~ns}$ \\
& $\mathrm{MN}$ & -0.24 & $\mathrm{~ns}$ \\
& $\mathrm{HA}$ & -0.48 & $\mathrm{~ns}$ \\
Stegastes partitus & $\mathrm{HN}$ & 0.15 & $\mathrm{~ns}$ \\
& $\mathrm{MA}$ & -0.21 & $\mathrm{~ns}$ \\
& $\mathrm{MN}$ & 0.19 & $\mathrm{~ns}$ \\
& $\mathrm{HA}$ & 0.19 & $\mathrm{~ns}$ \\
Halichoeres garnoti & $\mathrm{HN}$ & 0.12 & $\mathrm{~ns}$ \\
& $\mathrm{MA}$ & -0.24 & $\mathrm{~ns}$ \\
& $\mathrm{MN}$ & -0.51 & $\mathrm{~ns}$ \\
& $\mathrm{HA}$ & -0.43 & $\mathrm{~ns}$ \\
& $\mathrm{HN}$ & 0.01 & $\mathrm{~ns}$ \\
& & & \\
\hline
\end{tabular}


away from shelter sites, and adult $S$ partitus were observed chasing labrid recruits away from egg clutches. Second, the fact that these 3 species are the most common means that they will have higher encounter rates among each other than with less common species. For all species combined and for the 3 common species separately, the number of recruits at each biweekly census during the recruitment period (May to November) was not affected by the density of juveniles and adults of all species on any of the study reefs (Table 5)

Spearman rank correlation coefficients of the number of Thalassoma bifasciatum recruits in each biweekly census and the juvenile and adult density of each of the 3 common species during that census are shown for the recruitment period in Table 6 . Recruitment of $T$. bifasciatum was not correlated with juvenile and adult density of conspecifics on any of the study reefs. Recruitment was not affected by density of Stegastes partitus or Halichoeres garnoti on any of the study reefs. Similarly, recruitment of $S$. partitus was not correlated with density of juvenile and adult conspecifics on any of the study reefs (Table 7 ). Recruitment of $S$. partitus was also not affected by density of T. bifasciatum or H. garnoti on any of the study reefs.

For Halichoeres garnoti, recruitment was negatively correlated with juvenile and adult density of conspecifics on Miramar artificial reef $\left(r_{\mathrm{S}}=-0.89, \mathrm{p}<0.05\right)$, Heywoods artificial reef $\left(r_{\mathrm{S}}=-0.89, \mathrm{p}<0.05\right.$; analysis was restricted to those weeks during which $H$ garnoti was present) and Heywoods natural reef $\left(r_{S}=-0.78\right.$,

Table 6. Thalassoma bifasciatum. Spearman rank correlation coefficients of number of recruits in each biweekly census during the recruitment period (May to November) versus the juvenile and adult density of each of the 3 common species ( $T$. bifasciatum, Stegastes partitus, and Halichoeres garnoti) at the time of the census. Data are presented separately for each reef Probabilities have been adjusted using the DunnSidak method for experimentwise error rate. MA: Miramar artificial; MN: Miramar natural; HA: Heywoods artificial;

HN: Heywoods natural. ns: not significant

\begin{tabular}{|lllrl|}
\hline $\begin{array}{l}\text { Recruit } \\
\text { species }\end{array}$ & $\begin{array}{l}\text { Resident } \\
\text { species }\end{array}$ & Reef & \multicolumn{1}{c|}{$\mathrm{r}_{\mathrm{S}}$} & $\mathrm{p}$ \\
\hline T. bifasciatum & T. bifasciatum & $\mathrm{MA}$ & -0.21 & $\mathrm{~ns}$ \\
& & $\mathrm{MN}$ & 0.13 & $\mathrm{~ns}$ \\
& & $\mathrm{HA}$ & -0.67 & $\mathrm{~ns}$ \\
& $\mathrm{HN}$ & 0.45 & $\mathrm{~ns}$ \\
& S. partitus & $\mathrm{MA}$ & -0.19 & $\mathrm{~ns}$ \\
& & $\mathrm{MN}$ & 0.78 & $\mathrm{~ns}$ \\
& $\mathrm{HA}$ & -0.05 & $\mathrm{~ns}$ \\
& $\mathrm{HN}$ & 0.03 & $\mathrm{~ns}$ \\
& $\mathrm{MA}$ & 0.03 & $\mathrm{~ns}$ \\
& H. garnoti & $\mathrm{MN}$ & -0.55 & $\mathrm{~ns}$ \\
& & $\mathrm{HA}$ & 0.05 & $\mathrm{~ns}$ \\
& $\mathrm{HN}$ & -0.54 & $\mathrm{~ns}$ \\
& & & \\
\hline
\end{tabular}

$\mathrm{p}<0.05$; Table 8). Interestingly, there was no relationship between the density of $H$. garnoti on a given reef and the presence or absence of significant negative interactions. For example, density of $H$. garnoti did not affect recruitment of conspecifics on Miramar natural

Table 7. Stegastes partitus. Spearman rank correlation coefficients of number of recruits in each biweekly census during the recruitment perod (May to November) versus the juvenile and adult density of each of the 3 common species ( 5 partitus, Thalassoma bifasciatum, and Halichoeres garnoti) at the time of the census. Data are presented separately for each reef. Probabilities have been adjusted using the Dunn-Sidak method for experimentwise error rate. MA: Miramar artificial; MN: Miramar natural; HA: Heywoods artificial; HN: Heywoods natural. ns: not significant

\begin{tabular}{|lllrl|}
\hline $\begin{array}{l}\text { Recruit } \\
\text { species }\end{array}$ & $\begin{array}{l}\text { Resident } \\
\text { species }\end{array}$ & Reef & \multicolumn{1}{c}{$\mathrm{r}_{\mathrm{S}}$} & $\mathrm{p}$ \\
\hline S. partitus & S. partitus & $\mathrm{MA}$ & -0.69 & $\mathrm{~ns}$ \\
& & $\mathrm{MN}$ & -0.01 & $\mathrm{~ns}$ \\
& $\mathrm{HA}$ & -0.69 & $\mathrm{~ns}$ \\
& $\mathrm{HN}$ & 0.20 & $\mathrm{~ns}$ \\
& T bifasciatum & $\mathrm{MA}$ & 0.49 & $\mathrm{~ns}$ \\
& $\mathrm{MN}$ & 0.07 & $\mathrm{~ns}$ \\
& $\mathrm{HA}$ & 0.14 & $\mathrm{~ns}$ \\
& $\mathrm{HN}$ & 0.10 & $\mathrm{~ns}$ \\
& $\mathrm{MA}$ & -0.38 & $\mathrm{~ns}$ \\
& H. garnoti & $\mathrm{MN}$ & 0.46 & $\mathrm{~ns}$ \\
& & $\mathrm{HA}$ & 0.07 & $\mathrm{~ns}$ \\
& & $\mathrm{HN}$ & -0.34 & $\mathrm{~ns}$ \\
& & & & \\
& & &
\end{tabular}

Table 8. Hahchoeres garnoti. Spearman rank correlation coefficients of number of recruits in each biweekly census during the recruitment period (May to November) versus the juvenile and adult density of each of the 3 common species ( $H$. garnoti, Thalassoma bifasciatum, and Stegastes partitus) at the time of the census. Data are presented separately for each reef. Probabilities have been adjusted using the Dunn-Sidak method for experimentwise error rate. MA: Miramar artificial, MN: Miramar natural ${ }_{i} \mathrm{HA}_{\text {: }}$ Heywoods artificial; HN: Heywoods natural. ns: not significant

\begin{tabular}{|llccc|}
\hline $\begin{array}{l}\text { Recruit } \\
\text { species }\end{array}$ & $\begin{array}{l}\text { Resident } \\
\text { species }\end{array}$ & Reef & $\mathrm{r}_{\mathrm{S}}$ & $\mathrm{p}$ \\
\hline H. garnoti & H. garnoti & $\mathrm{MA}$ & -0.89 & $<0.05$ \\
& & $\mathrm{MN}$ & -0.23 & $\mathrm{~ns}$ \\
& $\mathrm{HA}$ & -0.89 & $<0.05$ \\
& $\mathrm{HN}$ & -0.78 & $<0.05$ \\
& T bifasciatum & $\mathrm{MA}$ & 0.03 & $\mathrm{~ns}$ \\
& $\mathrm{MN}$ & 0.28 & $\mathrm{~ns}$ \\
& $\mathrm{HA}$ & -0.26 & $\mathrm{~ns}$ \\
& $\mathrm{HN}$ & 0.19 & $\mathrm{~ns}$ \\
& S. partitus & $\mathrm{MA}$ & -0.12 & $\mathrm{~ns}$ \\
& $\mathrm{MN}$ & 0.50 & $\mathrm{~ns}$ \\
& $\mathrm{HA}$ & 0.54 & $\mathrm{~ns}$ \\
& $\mathrm{HN}$ & -0.29 & $\mathrm{~ns}$ \\
& & &
\end{tabular}


reef, which supported the highest density of that species. However, recruitment was inhibited by residents on Heywoods artificial reef, which supported the lowest density. It is possible that each reef has a different 'threshold density' or carrying capacity above which negative effects of residents on recruitment occur. This level may vary with factors such as substrate type (which can influence the abundance and quality of shelter), food or other resources. Recruitment of $H$. garnoti was not affected by density of Thalassoma bifasciatum or Stegastes partitus on any of the study reefs. In summary, only $H$. gamoti displayed density-dependent recruitment, and recruitment was only inhibited by conspecifics. Density of combined species or sympatric species did not affect recruitment of all species combined or of the 3 species individually. This observation suggests that the competitive interactions affecting recruitment of $H$. garnoti are primarily intraspecific

An index of post-recruitment mortality, reflecting the decline in density following peak recruitment (see 'Methods'), was calculated for all species combined and separately for the 3 common species on each study reef (Table 9). Possible effects of resident density on post-recruitment mortality were investigated by correlating the index of mortality with the density of juveniles and adults at the time of peak recruitment. Postrecruitment mortality of all species combined was not correlated with density of juveniles and adults of all

Table 9. Index of post-recruitment mortality $\left(I_{m}\right)$ and density at peak recruitment $\left(D_{p r}\right)$ on each reef for all species combined and for Thalassoma bifasciatum, Stegastes partitus, and Halichoeres garnoti. $I_{\mathrm{m}}$ is calculated as described in the 'Methods' MA: Miramar artificial reef; MN: Miramar natural reef; $\mathrm{HA}$ : Heywoods artificial reef; $\mathrm{HN}$ : Heywoods natural reef

\begin{tabular}{|c|c|c|c|}
\hline Species & Reef & $\begin{array}{l}I_{\%} \\
(\%)\end{array}$ & $\begin{array}{c}D_{p г} \\
\text { (no. per } 100 \mathrm{~m}^{2} \text { ) }\end{array}$ \\
\hline \multirow[t]{4}{*}{ All species combined } & $\mathrm{MA}$ & 6.3 & 485 \\
\hline & $\mathrm{HA}$ & 20.0 & 245 \\
\hline & $M N$ & 0.0 & 257 \\
\hline & $\mathrm{HN}$ & 0.0 & 464 \\
\hline \multirow[t]{4}{*}{ Thalassoma bifasciatum } & MA & 0.0 & 31 \\
\hline & $\mathrm{HA}$ & 5.8 & 40 \\
\hline & $\mathrm{MN}$ & 8.0 & 52 \\
\hline & $\mathrm{HN}$ & 12.2 & 107 \\
\hline \multirow[t]{4}{*}{ Stegastes partitus } & MA & 6.8 & 97 \\
\hline & $\mathrm{HA}$ & 2.0 & 42 \\
\hline & MN & 11.4 & 118 \\
\hline & $\mathrm{HN}$ & 19.2 & 140 \\
\hline \multirow[t]{4}{*}{ Halichoeres garnoti } & $\mathrm{MA}$ & 35.0 & 33 \\
\hline & $\mathrm{HA}$ & 0.0 & 7 \\
\hline & $M N$ & 37.0 & 51 \\
\hline & HN & 6.6 & 35 \\
\hline
\end{tabular}

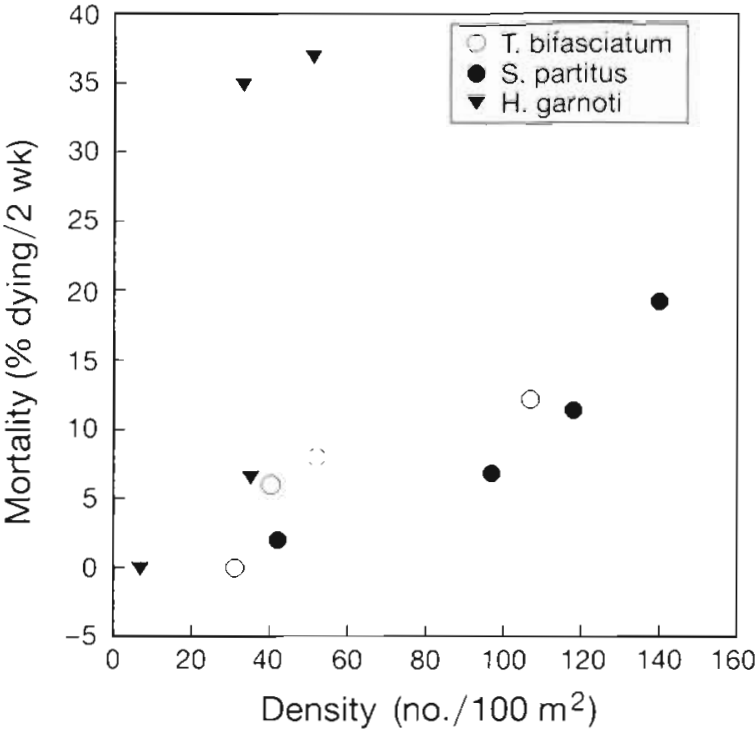

Fig. 3. Index of post-recruitment mortality of fishes on a reef versus density of juvenile and adult conspecifics on that reef at the time of peak recruitment. Data are presented separately for Thalassoma bifasciatum, Stegastes partitus and Halichoeres gamoti

species combined (Spearman rank correlation, $r_{\mathrm{S}}=$ $0.32, p>0.05)$. Similarly, post-recruitment mortality of Thalassoma bifasciatum, Stegastes partitus and Halichoeres garnoti was not significantly correlated with density of all species combined $\left(r_{S}=-0.2, p>0.05 ; r_{S}=\right.$ $0.8, p>0.05 ;$ and $r_{S}=0.4, p>0.05$, respectively). For T. bifasciatum, post-recruitment mortality was significantly correlated with density of juvenile and adult conspecifics ( $\mathrm{r}_{\mathrm{S}}=1.0, \mathrm{p}=0.0$; Fig. 3). Post-recruitment mortality of $S$. partitus was significantly correlated with increasing density of juvenile and aduit conspecifics $\left(\mathrm{r}_{\mathrm{S}}=1.0, \mathrm{p}=0.0\right.$, Fig. 3). There was a trend for post-recruitment mortality of $H$. garnoti to increase with density of juvenile and adult conspecifics, but the result was not significant with only 3 degrees of freedom $\left(r_{S}=0.8, p=0.11\right)$. It is interesting that on 3 of 4 reefs, recruitment of $H$. garnoti was strongly densitydependent, while post-recruitment mortality was less evidently density-dependent. Recruitment of $T$. bifasciatum and $S$. partitus displayed no density-dependence, while post-recruitment mortality of these species was strongly density-dependent. This suggests that the post-settlement processes regulating adult population size may vary with species.

In summary, the results suggest that post-recruitment mortality increases with increasing resident conspecific density, and that the processes resulting in the increased post-recruitment mortality are speciesspecific. It was not possible to determine the effects of interspecific competition on post-recruitment mortality 
among the 3 common species, as similarities between species in spatial patterns of recruitment, density, and mortality (probably in response to physical characteristics of the reef habitat; see Tupper 1989) would lead to spurious correlations of mortality of one species with population density of another

\section{DISCUSSION}

\section{Temporal variation in recruitment}

Although conclusions cannot be drawn from only 1 yr of data, recruitment of the common reef fishes in Barbados appeared to show seasonal variation. Most species studied recruited primarily from June to November. Thalassoma bifasciatum in Barbados recruited mainly in the summer months in 1984, 1985, and 1987-88, with a consistent seasonal peak from July to September (Tupper 1989, Hunt von Herbing \& Hunte 1991). Seasonal recruitment is widespread in reef fishes. For example, Williams \& Sale (1981) and Williams (1983) found strong seasonal variation in recruitment for a guild of pomacentrids on the Great Barrier Reef, and Williams (1983) commented on the 'remarkable constancy' in the timing of the annual mid-summer recruitment peak. Likely causes of seasonal recruitment include increases in adult spawning activity (Powles 1975, Hunt von Herbing \& Hunte 1991), seasonal changes in current patterns (Johannes 1978. Talbot et al. 1978, McFarland 1982), and/or seasonal variation in survival of planktonic larvae (Sale 1980, McFarland et al. 1985, Victor 1986). Note however that variation of survival in the plankton is believed to be highly stochastic (Victor 1986).

Several authors have found spawning and recruitment to follow similar seasanal patterns, separated by a period of time approximating the larval life of a typical reef fish (Munro et al. 1973, Watson \& Leis 1974. Luckhurst \& Luckhurst 1977). This suggests that seasonal variation in spawning may be the principal cause of seasonal variation in recruitment of reef fishes (Doherty 1991). Robertson et al. (1988) found that spawning and recruitment of Stegastes partitus in Panama were coupled, and that both spawning activity and recruitment followed a lunar cycle. Similar coupling of spawning and recruitment has been observed in S. partitus in Barbados (Tupper 1989). Hunt von Herbing (1988) suggests that recruitment of Thalassoma bifasciatum in Barbados also follows spawning by a time lag that complements the duration of the planktonic larval phase. These data indicate that temporal variation in recruitment of these 2 species results from variation in spawning rather than from variation in survival of planktonic larvae. Coupling of spawning and recruitment of $T$ bifasciatum (Hunt von Herbing 1988, Hunt von Herbing \& Hunte 1991) and S. partitus in Barbados is circumstantial evidence for the maintenance of primarily discrete island populations (see Hunt von Herbing 1988, Tupper 1989). If, in Barbados, reef fishes were maintained in relatively discrete island stocks, one might expect a consistent seasonal spawning regime to be coupled to a consistent seasonal recruitment regime. Interannual variation in the strength of the seasonal recruitment, rather than in the timing of recruitment, might then be attributed to processes in the plankton, such as predation or starvation, or to oceanographic processes such as wind and current anomalies.

\section{Spatial variation in recruitment}

Results of this study indicate that peaks of recruitment of several species are coherent over sites separated by distances ranging from meters to tens of kilometers. Doherty (1987) suggested that pre-settlement fish larvae are aggregated on at least 2 spatial scales, microscale patches of a few meters and mesoscale patches of tens of kilometers. Microscale patches are probably primarily influenced by the aggregation of schooling fishes such as Haemulidae (McFarland et al. 1985. Shulman 1985a). In Barbados, the tomtate Haemulon aurolineatum has been observed to settle in schools of up to several hundred, occupying an area of only 1 or $2 \mathrm{~m}^{2}$ (author's pers. obs.). Doherty (1987) found recruitment of a pomacentrid on the Great Barrier Reef to be coherent over a distance of $70 \mathrm{~km}$. Recruitment peaks in this study were coherent at the Heywoods and Miramar sites, about $10 \mathrm{~km}$ apart. It therefore appears that, as suggested by Powles (1975), fish larvae are aggregated off the west coast of Barbados in a mesoscale patch greater than $10 \mathrm{~km}$ in width. Note that the occurrence of a mesoscale larval patch does not preclude the possibility of microscale patch structure within it.

\section{Temporal and spatial variation in population densities}

A key issue in determining whether reef fish populations are space-limited or recruitment-limited is whether post-settlement events such as competition, disease and predation exert sufficient influence to override the effects of spatial and temporal variation in settlement patterns (Robertson 1988). In support of recruitment-limitation, Victor $(1983,1986)$ suggested that settlement controls patterns of adult densities in Thalassoma bifasciatum. Likewise, Doherty \& Williams 
(1988) reported that temporal patterns in adult and juvenile density of Pomacentrus amboinensis appeared to reflect successive peaks in recruitment. However, Jones (1991) states that in the majority of recent studies, changes in adult population size do not reflect the history of recruitment. In the present study, temporal variation in population density did not differ significantly from uniform. The observation that recruitment varies temporally but population density does not suggests that post-settlement processes following recruitment pulses are strong enough to quickly return total population numbers to pre-settlement values. In addition, although mean recruitment over the 12 mo period did not differ on different reefs, mean population density did. This suggests that mean population density on a reef is not primarily controlled by recruitment strength to the reef. Together the results imply that over the course of this study, reef fish populations in Barbados were close to carrying capacities of the reefs, i.e. that they were more typically 'space-limited' than 'recruitment-limited'.

\section{Prior resident effects}

Victor $(1983,1986)$ argued that Thalassoma bifasciatum in Panama is recruitment-limited, and hence that there are consistently fewer fish than the habitat can support. He therefore suggested that effects of residents on recruitment rates and post-settlement mortality should be negligible. Doherty $(1982,1983)$, working on territorial pomacentrids on the Great Barrier Reef, concluded that recruitment and juvenile survivorship were independent of resident density. In contrast to the above results, Shulman et al. (1983) found that density of resident fishes on reefs in the Virgin Islands (Caribbean) affected settlement in at least 2 ways; first, settlement of 3 species decreased in the presence of a territorial pomacentrid, and second, prior settlement of a juvenile predator lowered successful recruitment of 2 prey species. Shulman et al. (1983) suggested that such processes would influence the population size and fish assemblage structure on reefs. High densities of resident conspecifics have been shown to reduce growth rates of newly settled fish in a number of studies (Jones 1987 a, b, 1988, Forrester 1990). Hunte \& Côté (1989) found that territory size of resident blennies Ophioblennius atlanticus on Barbados reefs decreased significantly following recruitment pulses, and that postrecruitment mortality was density-dependent. They therefore suggested that populations of $O$. atlanticus in Barbados were space-limited. In the present study, the density of combined species did not affect the recruitment of all species to the reef, or post-recruitment mortality of any species on the reef. However, significant negative interactions were detected between recruitment rate and conspecific resident density of Halichoeres garnotion 3 of 4 reefs. Moreover, post-recruitment mortality of $T$. bifasciatum and Stegastes partitus was significantly correlated with juvenile and adult density at the time of peak recruitment. These results suggest that competitive interactions at or following settlement may limit the number of successful recruits to reefs and hence affect fish population size. The results also suggest that post-recruitment processes regulating adult population size may vary among species or from reef to reef. The fact that the significant competitive interactions are intraspecific may be interpreted as supporting the hypothesis that coral reef fishes have evolved specialized, species-specific niche requirements, arguably in response to past interspecific competition. These specific niche requirements now reduce interspecific interactions, and thereby promote species coexistence and high species richness. In summary, given that significant prior resident effects were detected in this study in certain circumstances and not in others, it appears, as discussed by Jones (1991), that limitation of reef fish populations by interactions on the reef or by recruitment is a matter of degree, i.e. that the opposing theories of space limitation and recruitment limitation should be perceived as extremes on a continuum. Further investigations into the processes regulating populations of reef fishes should adopt a more pluralistic perspective, addressing both pre- and postrecruitment events.

Acknowledgements. Assistance in the field was provided by Ione Hunt von Herbing and Ronald Hinds. Funding for the research was provided by Natural Sciences and Engineering Research Council Operating Grant no. AO264 to W.H. and by a Metcalf Foundation Postgraduate Fellowship to M.T Critical reviews by $\mathrm{I}$. Hunt von Herbing and 3 anonymous reviewers greatly improved the quality of this paper.

\section{LITERATURE CITED}

Bohnsack, J. A. (1983). Species turnover and the order versus chaos controversy concerning reef fish community structure. Coral Reefs 1: 223-228

Connell, S. D., Jones, G. P. (1991). The influence of habitat complexity on postrecruitment processes in a temperate reef fish population. J. exp. mar. Biol. Ecol. 151. 271-294

Doherty, P. J. (1982). Coral reef tishes: recruitment-limited assemblages? In: Gomez, E., Birkeland, C., Buddemeier, R., Johannes, R., Marsh, J., Tsuda, R. (eds.) Proceedings of the Fourth International Coral Reef Symposium, Manila, Vol. 2. Diliman, Quezon City, p. 465-470

Doherty, P. J. (1983). Tropical territorial damselfishes: is density limited by aggression or recruitment? Ecology 64: $176-190$

Doherty, P. J. (1987). The replenishment of populations of coral reef fishes, recruitment surveys, and the problems of variability manifest on multiple scales. Bull. mar. Sci. 41(2): $411-422$ 
Doherty, P. J. (1991). Spatial and temporal patterns in recruitment. In: Sale, P. F. (ed.) The ecology of fishes on coral reefs. Academic Press, San Diego, p. 261-293

Doherty, P. J., Williams, D. MCB. (1988). The replenishment of coral reef fish populations. Oceanogr. mar. Biol. A. Rev. 26: $487-551$

Forrester, G. E. (1990). Factors affecting the juvenile demography of a coral reef fish population. Ecology 71 . $1666-1681$

Hunt von Herbing, I. (1988). Reproduction and recruitment in the bluehead wrasse, Thalassoma bifasciatum in Barbados. M.Sc. thesis, McGill University, Montreal

Hunt von Herbing, I., Hunte, W. (1991). Spawning and recruitment of the bluehead wrasse Thalassoma bifasciatum in Barbados. Mar. Ecol. Prog. Ser. 72: 49-58

Hunte, W. (1987). Derelict vehicles as artificial reefs in Barbados (unpublished report). Bellairs Research Institute of McGill University, St. James, Barbados

Hunte, W., Côté, I. M. (1989). Recruitment in the redlip blenny Ophioblennius atlanticus: is space limiting? Coral Reefs 8: 49-50

Johannes, R. E. (1978). Reproductive strategies of coastal marine fishes in the tropics. Environ. Biol. Fish. 3; 65-84

Jones, G. P. (1986). Food availablity affects growth in a coral reef fish. Oecologia 70: 136-139

Jones, G. P. (1987a). Competitive interactions among adults and juveniles in a coral reef fish. Ecology 68: $1534-1547$

Jones, G. P. (1987b). Some interactions between residents and recruits in two coral reef fishes. J exp. mar. Biol. Ecol. 114: $169-182$

Jones, G. P. (1988). Experimental evaluations of the effects of habitat structure and competitive interactions on the juveniles of two coral reef fishes. J. exp. mar Biol. Ecol. 123: $115-126$

Jones, G. P. (1990). The importance of recruitment to the dynamics of a coral reef fish population. Ecology 71 : 1691-1698

Jones, G. P. (1991). Postrecruitment processes in the ecology of coral reef fish populations: a multifactorial perspective. In: Sale, P. F. (ed.) The ecology of fishes on coral reefs. Academic Press, San Diego, p. 294-330

Luckhurst, B. E., Luckhurst, K. (1977). Recruitment patterns of coral reef fishes on the fringing reef of Curacao, Netherlands Antilles. Can. J. Zool. 55: 681-689

McFarland, W. N. (1982). Recruitment patterns in tropical reef fishes. In: Huntsman, G. R., Nicholson, W. R., Fox, W. W. Jr (eds.) The biological basis for reef fishery management. NOAA Tech. Memo. NMFS-SEFC-80. NOAA, Washington, DC, p. 83-91

McFarland, W. N., Brothers, E. B., Ogden, J C., Shulman, M. J., Bermingham, E. L., Kotchian-Prentiss, N. M. (1985). Recruitment patterns in young french grunts Haemulon flavolineatum (Family Haemulidae), at St. Croix, U.S.V.I. Fish. Bull. U.S. 83: 413-426

Milicich, M. J., Meekan, M. G., Doherty, P. J. (1992). Larval supply: a good predictor of recruitment of three species of reef fish (Pomocentridae). Mar. Ecol. Prog. Ser. 86: $153-166$

Munro, J. L., Gaut, V. G., Thompson, R., Reeson, P. H. (1973) The spawning seasons of Caribbean reef fishes. J. Fish Biol. 5: 69-84

Ogden, J. C., Ebersole, J. P. (1981). Scale and community structure of coral reef fishes: a long-term study of a large artificial reef. Mar. Ecol. Prog. Ser. 4: 97-103

This article was presented by P. J. Wangersky (Senior

Editorial Advisor), Victoria, B.C., Canada
Powles, H. W. (1975). Abundance, seasonality, distribution and aspects of the ecology of some larval fishes off Barbados. Ph.D. thesis, McGill University, Montreal

Robertson, D. R. (1973). Field observations on the reproductive behavior of a pomacentrid fish, Acanthochroms polyacanthus. Z. Tierpsychol. 32: 319-324

Robertson, D. R. (1988). Abundances of surgeonfishes on patch-reefs in Caribbean Panama: due to settlement, or post-settlement events? Mar Biol. 97: 495-501

Robertson, D. R., Green, D. G., Victor, B. C. (1988). Temporal coupling of production and recruitment of larvae of a Caribbean reef fish. Ecology 69(2): 370-381

Sale, P. F. (1977). Maintenance of high diversity in coral reef fish communities. Am. Nat. 111:337-359

Sale, P. F. (1978). Coexistence of coral reef fishes - a lottery for living space. Environ. Biol. Fish. 3: 85-102

Sale, P. F. (1980). The ecology of fishes on coral reefs. Oceanogr mar. Biol. A. Rev. 18: 367-421

Sale, P. F. (1991). Reef fish communities: open nonequilibrial systems. In: Sale, P. F. (ed.) The ecology of fishes on coral reefs. Academic Press, San Diego, p. 564-598

Sale, P. F., Ferrell, D. J. (1988). Early survivorship of juvenile coral reef fishes. Coral Reefs 7: 117-124

Shulman, M. J. (1984). Resource limitation and recruitment patterns in a coral reef fish assemblage. J. exp. mar. Biol. Ecol. 74: 85-109

Shulman, M. J. (1985a). Coral reef assemblages: intra- and interspecific competition for shelter sites. Environ. Biol. Fish. 13: 81-92

Shulman, M. J. (1985b). Recruitment of coral reef fishes: effects of distribution of predators and shelter. Ecology 66 $1056-1066$

Shuiman, M. J., Ogden, J. C., Ebersole, J. P., McFarland, W. N., Miller, S. L., Wolf, N. G. (1983). Prionity effects in the recrutment of juvenile coral reef fishes. Ecology 64 1508-1513

Sokal, R. R., Rohlf, F. J. (1981). Biometry, 2nd edn. Freeman, San Francisco

Talbot, F. H., Russell, B. C., Anderson, G. R. V. (1978). Coral reef fish communities: unstable, high diversity systems? Ecol. Monogr. 48: 425-440

Tupper, M. (1989). Recruitment and assemblage structure of coral reef fishes in Barbados. M.Sc. thesis, McGill University, Montreal

Victor, B. C. (1983). Recruitment and population dynamics of a coral reef fish. Science 219: 419-420

Victor, B. C. (1986). Larval settlement and juvenile mortality in a recruitment-limited coral reef fish population. Ecol. Monogr. 56: 145-160

Watson, W., Leis, J M. (1974). Ichthyoplankton on Kaneohe Bay, Hawaii. A one year study of fish eggs and larvae. Univ. Hawaii Sea Grant Tech. Rep. TR-75-01 Univ. Hawaii Sea Grant, Honolulu

Wilkinson, L. (1990). SYSTAT the system for statistics. SYSTAT, Inc., Evanston, IL

Williams, D. MCB. (1983). Daily, monthly and yearly variability in recruitment of a guild of coral reef fishes. Mar. Ecol. Prog. Ser 10: 231-237

Williams, D. MCB., Russ, G., Doherty, P. J. (1986). Reef fish: large-scale distribution and recruitment. Oceanus 29(2): $76-82$

Williams, D. McB., Sale, P. F. (1981). Spatial and temporal patterns of recruitment of juvenile coral reef fishes to coral habitats within One Tree Lagoon, Great Barrier Reef. Mar. Biol. 65: 245-253

Manuscript first received: June 17, 1993

Revised version accepted: February 15, 1994 